\title{
Possibility of Utilizing Neoseiulus californicus (Mcgregor) (Acari: Phytoseiidae) to Control Oxycenus niloticus Zaher and Abou-Awad (Acari: Eriophyidae)
}

\author{
A. A. Ebrahim; A. A. M. Abdallah aind K. M. Elsayed \\ Plant Protection Research Institute, Agricultural Research Center, Dokki, Giza, Egypt
}

\begin{abstract}
The life history and predation rate of the predatory mite, Neoseiulus californicus (McGregor) on the olive mite, Oxycenus niloticus Zaher and Abou-Awad andTetranychus urticae Koch, were separately studied at $25^{\circ} \mathrm{C}$ and $60-70 \%$ R.H. O. niloticus was collected from the upper surface of olive leaves Olea europaea L. and the two-spotted spider mite, T. urticae from castor oil plant Ricinus communis. All movable stages of the predator were able to devour $O$. niloticus more than $T$. urticae adult female.Predation rate, life cycle, and oviposition periods varied depending on type of prey. Predator larva, protonymph, deutonymph and adult female and male consumed 1.2, 6.8, 7.9, 11.7 and 10.1 of $O$. niloticus adults or $0.1,1.9,2.8,3.6$ and 3.1 of $T$. urticae adults per day, respectively. Nevertheless, the intrinsic rate of natural increase $\left(\mathrm{r}_{\mathrm{m}}\right)$ was lower on $O$. niloticus than onT. urticae, 0.158 and 0.210 , respectively. Results indicated the effectiveness of $N$. californicus as an important biological control agent against $O$. niloticus.
\end{abstract}

Key Words: Neoseiulus californicus, Development, Life table, Predation, Oxycenus niloticus, Tetranychus urticae.

\section{INTRODUCTION}

Many eriophyid species are of certain economic importance as typical pests of perennial and annual plants (Lindquist, 1996). Over 3000 eriophyid species assigned to nearly 300 genera, are known in the world fauna (Amrine1996 and Lindquist \&Amrine1996). Members of the eriophyid and diptilomiopid families live on trees, shrubs, and herbaceous plants (Zaher, 1984). Numbers of Oxycenus niloticus are normally found on the upper surface of terminal olive leaves and produce some leaf pitting and deformation of buds as well as leaves.

González et al., 2000 reported that populations of the phytoseiid mites Neoseiulus californicus and Typhlodromus sp. were associated with the colonies of eriophyids on olive trees. The former is considered the most efficient predator of tetranychid mites.

$N$. californicus appears to act as a generalist tetranychid predator and can initiate multiple attacking behaviors. On the other hand,its behavior suggests that it is opportunistic and capable of capturing several deferent types of prey (TakanoLeeand Hoddle, 2002). It feeds successfully on eriophyid mites as it quickly accepts $A$. lycopersicus prey. Predator female devoured 23.89 eriophyid adults, (Castagnoli et al., 2003).

The current study aims to investigate the possibility of Neoseiulus californicusto to predate on Oxycenus niloticus under laboratory conditions. Biological parameters were used to evaluate the performance of this phytoseiid on olive for controlling $O$. niloticus.

\section{MATERIALS AND METHODS}

Life history characteristics and predation of $N$. californicus on the eriophyid $O$. niloticus and the tetranychid $T$. urticae were conducted in the laboratory at $25 \pm 2{ }^{\circ} \mathrm{C}$ and $70 \pm 5 \%$ R.H. The eriophyid mite, $O$. niloticus was collected from the upper surface of olive leaves Olea europaea L. and the two spotted spider mite from the lower surface of castor oil plant Ricinus communis leaves. Petri dishes as rearing units were coated on its lower surface and sides with a layer of moist cotton wool and put upside down in large plate's full withwater to provide moisture continuously. Five small discs of mulberry leaves, Morus alba L. (about $2.5 \mathrm{~cm}$ diameter), were put upside down on the moist cotton. Five Petri dishes were assigned for rearing $T$. urticae and others for rearing $\dot{O}$. niloticus.

A layer of wet cotton was placed around each leaf disc as barrier to confine the predator to a definite area. One egg of $N$. californicus was put on each disc for development to the adult stage and observed twice daily. When the $N$. californicus larvae hatched, a certain number of $T$. urticae adult females were placed on each disc or a small piece of olive with known number of $O$. niloticus was placed on each disc. Thus, one $N$. californicus larva was liberated on each disc, and the numbers of preys eaten during its larval, protonymphal, deutonymphal stages and adult female or male were recorded. Surplus food was provided whenever the supply became low or the olive leaves needed to be changed. 


\section{Female survival and reproduction:}

The fecundity of $\dot{N}$. californicus was determined at $25^{\circ} \mathrm{C}$. Before the final molt of the female deutonymph, one adult male was provided and was ensured to mate once. The male was then removed and observations were made twice a day until the first egg was laid. Thereafter, the number of laid eggs was recorded every 24 hours until the female died. All resulting hatched larvae were transferred to new excised mulberry leaves and reared until adult stage to record the sex ratio of resultant progeny. Oviposition, pre-and post-oviposition periods were also recorded. The intrinsic rate of natural increase $\left(\mathrm{r}_{\mathrm{m}}\right)$ at $25^{\circ} \mathrm{C}$ was estimated according to the equation given by Birch (1948). The following life history parameters;net reproductive rate (Ro), mean generation time (T), and finite rate of increase $(\lambda)$ were determined after Hulting et al. 1990. Longevity and fecundity data were analysed with Mann-Whitney U-test or Kruskal-Wallis test.

\section{RESULTS AND DISCUSSION}

The daily average number of $T$. urticae adult females and $O$. niloticus as prey consumed by developmental stages of $N$. californicus was listed in table 1 . The daily average preyed adult females of $T$. urticae by larva, protonymph, deutonymph and adult female and male were $0.1 \pm 0.32,1.9 \pm 0.90,2.8$ $\pm 0.74,3.6 \pm 0.86$ and $3.1 \pm 0.86$, respectively. The developmental stages of $N$. californicus accepted $O$. niloticus as prey by high consumption rate. The daily average of $O$. niloticus stages consumed by predator larva, protonymph, deutonymph, and adult female and male were $1.2 \pm 0.8,6.8 \pm 3.6,7.9 \pm 3.4$, $11.7 \pm 9.2$ and $10.0 \pm 8.4$, respectively.

The estimated values of life table parameters for $N$. californicus are listed in table 2 . The mean generation time ( $\mathrm{T}$, in days) of $N$. californicus was 17.7 and 13.7 when the prey was $T$. urticae or $O$. niloticus, respectively. The net reproductive rate (Ro) was higher on T. urticae as prey than on $O$. niloticus, which was 23.21 and 17.46, respectively. The intrinsic rate of natural increase $\left(r_{m}\right)$ was higher on $T$. urticae than on $O$. niloticus, which was 0.210 and 0.158 , respectively. Also, the finite rate of increase $(\lambda)$ was higher on $T$. urticae as prey than on $O$. niloticus, being 1.24 and 1.17 , respectively. However, the sex ratio (female: male) was slightly lower in T. urticae as prey than in $O$. niloticus which was2.0:1 and 2.1:0.9, respectively.

The duration and rate of reproduction of $N$. californicus are shown on table 3. The preoviposition, oviposition, postoviposition periods, total no. of eggs/female, average no. of eggs/female/day and adult longevity with $T$. urticae as prey were $1.59,17.44,11.23,32.36,1.86$ and 29.76 , respectively. These values decreased when using $O$. niloticus to $1.39,11.35,8.84,19.64,1.73$ and 21.08 , respectively.

From the previous results, it could be noticed that, the all developmental stages of $N$. californicus predated on $O$. niloticus more than $T$. urticae as prey. Also, the predator adult female consumed more prey than other development stages.

Present result as other previous studies indicated that $N$. californicus can play a good role in the control of O. niloticus, as it was able to quickly recognize, attack and kill the prey and to utilize it as food in order to increase its population (Castagnoli et al., 2003), and can reduce its population densities as a generalist predator (Mc Murtry and Rodriguez 1987; Mc Murtry and Croft 1997 and Croft et al., 1998). This species (N. californicus) can survive and reproduce on different mite and insect species and pollens (Castagnoliand Falchini, 1993; Sabelis and Van Rijn, 1997 and Croft et al., 1998).

However results may be promising of utilizing $N$. californicus in the biological control of $O$. niloticus; with depend on the ability of the predator to adapt to olive tree as host plant. This needs further studies to establish such adaptation.

The intrinsic rate of natural increase $\left(\mathrm{r}_{\mathrm{m}}\right)$ is one of the criteria that are extensively used in evaletating the efficacy of many predatory mites against spider mites (Tanigoshi1982; Sabelis1985a). Our results revealed that at $25^{\circ} \mathrm{C}$, the $\mathrm{r}_{\mathrm{m}}$ value obtained from $N$. californicus fed solely on adult females of $T$. urticae was 0.210 , higher than that obtained with feeding on adults of $O$. niloticus which was 0.158 . Gotoh et al.2004 reported an $\mathrm{r}_{\mathrm{m}}$ value of 0.274 at $25^{\circ} \mathrm{C}$ for the Japanese strain fed solely on eggs of $T$. urticae. Although the daily consumption rate of adult female of $T$. urticae was lower than for $O$. niloticus by $N$. californicus, but the high rate of daily consumption of $O$. niloticus was offset by lower intrinsic rate of natural increase $\mathrm{r}_{\mathrm{m}}$ value. Our result indicated that $T$. urticae was the suitable prey mite for mass-rearing where $N$. californicus was capable to achieve higher $\mathrm{r}_{\mathrm{m}}$. This is the most common functional response of the phytoseiid species to an increasing density of spider mites (Sabelis, 1985b). Also our study indicated that $N$. californicus had experienced an alternative mass rearing diet. It showed ability to adapt rapidly on selective prey(Castagnoliand Simoni, 1999). It is known that a wild predator strain needs several generations to utilize a new food 
Table (1): Daily average adult females of $T$. urticae (T. u) adults and $O$. niloticus (O.n) consumed by $N$. californicus developmental stages at $25 \pm 2{ }^{\circ} \mathrm{C}$ and $70 \pm 5 \%$ R.H.

\begin{tabular}{lcc}
\hline Predator stage & T.u \pm SD & O.n \pm SD \\
\hline Larva & $0.1 \pm 0.32$ & $1.2 \pm 0.8$ \\
\hline Protonymph & $1.9 \pm 0.90$ & $6.8 \pm 3.6$ \\
\hline Deutonymph & $2.8 \pm 0.74$ & $7.9 \pm 3.4$ \\
\hline Female & $3.6 \pm 0.86$ & $11.7 \pm 9.2$ \\
\hline Male & $3.1 \pm 0.86$ & $10.0 \pm 8.4$ \\
\hline T.
\end{tabular}

Table (3): Duration in days and egg production of $N$. californicus adult females when reared on different preys; adult females of T. urticae (T.u) and $\mathrm{O}$. niloticus stages; at $25 \pm 2{ }^{\circ} \mathrm{C}$ and $70 \pm 5 \%$ R.H.

\begin{tabular}{lcc}
\hline Parameter & T.u & O.n \\
\hline Preoviposition period & 1.59 & 1.39 \\
\hline Oviposition period & 17.44 & 11.35 \\
\hline Postoviposition period & 11.23 & 8.84 \\
\hline Total no. of eggs/female & 32.36 & 19.64 \\
\hline Average no. of eggs/female/day & 1.86 & 1.73 \\
\hline Total adult longevity & 29.76 & 21.08 \\
\hline
\end{tabular}

Table (2): Life table parameters of $N$. californicus reared on $T$. urticae (T.u) and O. niloticus (O.n), adult females at $25 \pm 2^{\circ} \mathrm{C}$ and $70 \pm 5 \%$ R.H.

\begin{tabular}{cccccc}
\hline Prey & $\begin{array}{c}\text { Mean generation } \\
\text { time }(\mathrm{T}, \text { days) }\end{array}$ & $\begin{array}{c}\text { Net reproductive } \\
\text { rate (Ro })\end{array}$ & $\begin{array}{c}\text { Intrinsic rate of natural } \\
\text { increase }\left(\mathrm{r}_{\mathrm{m}} / \text { day }\right)\end{array}$ & $\begin{array}{c}\text { Finite rate of } \\
\text { increase }(\lambda)\end{array}$ & $\begin{array}{c}\text { Sex ratio } \\
(\mathrm{F}: \mathrm{M})^{\mathrm{a}}\end{array}$ \\
\hline $\mathrm{T} . \mathrm{u}^{\mathrm{b}}$ & 17.7 & 23.21 & 0.210 & 1.24 & $2.0: 1$ \\
\hline $\mathrm{O} . \mathrm{n}^{\mathrm{c}}$ & 13.7 & 17.46 & 0.158 & 1.17 & $2.1: 0.9$ \\
\hline${ }^{\mathrm{a}}$ Female and male proportion & ${ }^{\mathrm{b}}$ T. urticae & ${ }^{\mathrm{c}}$ O. niloticus & &
\end{tabular}

source for development and reproduction efficiently (Castagnoliand Liguori, 1994; Castagnoli et al., 1996). Therefore, it can be concluded that improving of intrinsic rate of naiural increase, $\mathrm{r}_{\mathrm{m}}$ values can be obtained by rearing $N$. californicus on $O$. niloticus with several generations. This could be improved naturally, when the eggs of $O$. niloticus are available on the olive leaves by high rate during applying the biological control program.

\section{REFERENCES}

Amrine, J. W. JR. 1996. Keys to the world genera of - the Eriophyidae (Acari: Prostigmata). Indira Publishin House, West Bloomfield, Michigan, $187 \mathrm{pp}$.

Birch, L.C. 1948. The intrinsic rate of natural increase of an insect population. Journal of Animal Ecology, 17: 15-26.

Castagnoli, M. and Falchini, L.1993. Suitability of Polyphagotarsonemus latus (Banks) (Acari: Tarsonemidae) as prey for Amblyseius californicus (McGregor) (Acari: Phytoseiidae). Redia,76(2): 273-279.

Castagnoli, M. and Liguori, M. 1994.Utilizzazione di pollinene H'allevamentomassale di Typhlodromus exhilaratus Ragusa e Amblyseius californicus (McGregor) (Acari: Phytoseiidae) in Viggiani G (ed.) MAF, Convegno "LotaBiologica) Acireale 1991, Istituto di PatokogiaVegetale, Roma: 139-144.
Castagnoli, M. and Simoni, S. 1999. Effect of longterm feeding history on functional and numerical response of Neoseiulus californicus (Acari: Phytoseiidae). Experimental and Applied Acarology, 23: 217-234.

Castagnoli, M.; Simoni, S. and Biliotti, N. 1996. Mass-rearing of Amblyseius californicus on two alternative food sources. In: Bruin, J., van der Geest, L.P.S. \& Sabelis, M.W. (Eds.), Ecology and Evolution of the Acari, Proceedings of the 3rd Symposium of the European Association of Acarologists, 1-5 July 1996, Amsterdam, The Netherlands. Kluwer Academic Publishers: 425-431.

Castagnoli, M.; Simoni, S. and Liguori, M. 2003. Evaluation of Neoseiulus californicus (McGregor) (Acari Phytoseiidae) as a candidate for the control of Aculops lycopersici (Tryon) (Acari: Eriophyidae): a preliminary study. Redia, 86: 97-100.

Castagnoli, M.; Liguori, M.; Liguri, M.; Simoni, S. and Guid, S. 1998. Torato as host plant: Effect on some biological parameters of Phytoseiulus persimilis Athias-Henriot and Tetranychus uriteae strain. Redia, 81: 93-99.

Croft, B. A.; Monetti, L. N. and Pratt, P. D.1998.Comparative life histories and predation types: Are Neoseiulus californicus and $N$. fallacies (Acari: Phytoseiidae) similar type II selective predators of spider mites? Environ. Entomol., 27: 531-538. 
González, M. I.; Alvarado, M.; Durán, J. M. and De La Rosa A. Y Serrano, A. 2000.Los eriófidos (Acariña: Eriophyidae) delolivar de la provincial de Sevilla. Problemáticay control.Bol. San. Veg. Plagas, 26: 203-214.

Gotoh, T.; Yamaguchi, K. and Mori, K. 2004. Effect - of temperature on life history of the predatory mite Amblyseius californicus (Acari: Phytoseiidae). Experimental and Applied Acarology, 32: 15-30.

Hulting, F. L.; Orr, D. B. and Obrycki, J. J. 1990. A computer program for calculation and statistical comparison of intrinsic rates of increase and associated life table parameters. Florida Entomologists, 73: 601-612.

Lindquist, E. E. 1996. External anatomy and notation of structures. In: Lindquist, E. E.; Sabelis, M. W. and Bruin, J. (Editors), Eriophyid mites - Their biology, natural enemies and control. Elsevier Science Publ., Amsterdam, 6: 130.

Lindquist, E. E. and Amrine, J. W. Jr. 1996. Systematics, diagnoses for major taxa, and keys to families and genera with species on plant of economic importance. In: Lindquist, E. E.; Sabelis, M. W. and Bruin, J. (Editors), Eriophyid mites - Their biology, natural enemies and . control. Elsevier Science Publ., Amsterdam, 6: 33-87.

Mc Murtry, J. A. and Croft, B. A. 1997. Life styles of phytoseiid mites and their roles in biological control. Annu. Rev. Entomol., 42: 291-321.
Mc Murtry, J. A. and Rodriguez, J. G. 1987.Nutritional ecology of phytoseiid mites.In F. Slansky, Jr. and J. G. Rodriguez [eds], Nutritional ecology of insects, mites, spiders and related invertebrates. Wiley, New York: 609-644.

Sabelis, M.W. 1985a. Capacity for population increase. In: Helle, W. \& Sabelis, M.W. (Eds), Spider Mites.Their Biology, Natural Enemies and Controls, Vol. 1B. Elsevier, Amsterdam: 35-41.

Sabelis, M.W. 1985b. Predation on spider mites. In world crop pests. Spider mites, their biology, natural enemies and control, Vol. IB, W. Helle and M.W. Sabelis (eds.), Elsevier, Amsterdam: 103-129.

Sabelis, M. W. andVan Rijn, P. C. J. 1997. Predation by insects and mites. In: Lewis T. (ed.). Thrips as Crop Pests. CAB International, Wallingford: 259-354.

Takano-Lee M. and Hoddle, M. 2002. Predatory behaviors of Neoseiulus californicus and Galendromus helveolus. (Acari: Phytoseiidae) attacking Oligonychus perseae (Acari: Tetranychidae). Exp. Appl. Acarol., 26: 13-26.

Tanigoshi, L.K. 1982. Advances in knowledge of the Phytoseiidae. In: Hoy, M.A. (Ed), Recent Advances in Knowledge of the Phytoseiidae. Agricultural Sciences Publications, Berkeley: $1-22$.

Zaher, M. A. 1984. Survey and ecological studies on phytophagous, predaceous and soil mites in Egypt PL 480 Programme U. S. A. project NO. EG-ARS-30 Grant NO.FG-EG-130pp. 